
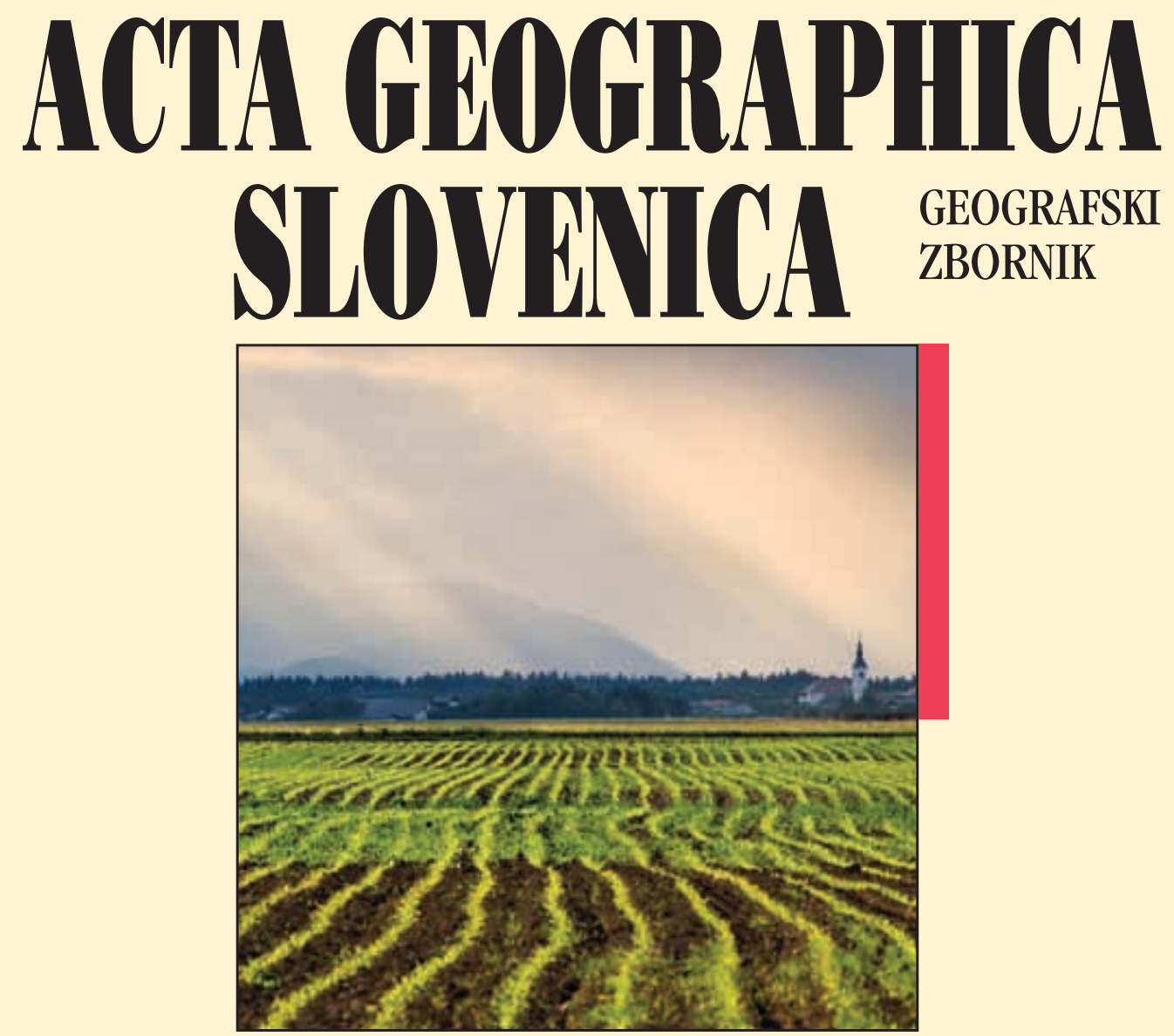

2018

58 


\section{ACTA GEOGRAPHICA SLOVENICA GEOGRAFSKI ZBORNIK \\ 58-1 • 2018}

\section{Contents}

Milivoj B. GAVRILOV, Slobodan B. MARKOVIĆ, Natalija JANC, Milena NIKOLIĆ, Aleksandar VALJAREVIĆ, Blaž KOMAC,

Matija ZORN, Milan PUNIŠIĆ†, Nikola BAČEVIĆ

Assessing average annual air temperature trends using the Mann-Kendall test in Kosovo

Liza STANČIČ, Blaž REPE

Post-fire succession: Selected examples from the Karst region, southwest Slovenia

Mirko GRČIĆ, Ljiljana GRČIĆ, Mikica SIBINOVIĆ

The geographical position of the town of Rasa based on Porphyrogenitus and medieval maps

Special issue - Agriculture in modern landscapes:

A factor hindering or facilitating development?

Nika RAZPOTNIK VISKOVIĆ, Blaž KOMAC

Agriculture in modern landscapes: A factor hindering or facilitating development?

Iwona MARKUSZEWSKA

Conflicts between legal policy and rural area management in Poland

Mojca FOŠKI

The (non)usefulness of the Register of Existing Agricultural and Forest

Land Use for monitoring the processes in urban areas

Maja POLENŠEK, Janez PIRNAT

Forest Patch Connectivity: The Case of the Kranj-Sora Basin, Slovenia

Karmen PAŽEK, Aleš IRGOLIČ, Jernej TURK, Andreja BOREC, Jernej PRIŠENK, Matej KOLENKO, Črtomir ROZMAN

Multi-criteria assessment of less favoured areas: A state level

Miomir M. JOVANOVIĆ, Miško M. MILANOVIĆ, Matija ZORN

The use of NDVI and CORINE Land Cover databases for forest management in Serbia

Darijo ILIĆ, Jože PANJAN

Nitrogen and Phosphorus Pollution in Goričko Nature Park

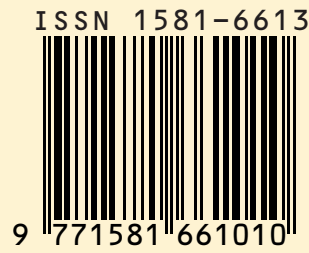




\section{ACTA GEOGRAPHICA SLOVENICA}

58-1

2018

ISSN: 1581-6613

COBISS: 124775936

UDC/UDK: 91

(C) Geografski inštitut Antona Melika ZRC SAZU 2018

International editorial board/mednarodni uredniški odbor: Michael Bründl (Switzerland), Rok Ciglič (Slovenia), Matej Gabrovec (Slovenia), Peter Jordan (Austria), Drago Kladnik (Slovenia), Blaž Komac (Slovenia), Andrej Kranjc (Slovenia), Dénes Lóczy (Hungary), Simon McCharty (United Kingdom), Slobodan Marković (Serbia), Milan Orožen Adamič (Slovenija), Drago Perko (Slovenia), Marjan Ravbar (Slovenia), Aleš Smrekar (Slovenia), Annett Steinführer (Germany), Mimi Urbanc (Slovenia), Matija Zorn (Slovenia).

Editor-in-Chief/glavni urednik: Blaž Komac; blaz@zrc-sazu.si

Executive editor/odgovorni urednik: Drago Perko; drago@zrc-sazu.si

Chief editor for physical geography/glavni urednik za fizično geografijo: Matija Zorn; matija.zorn@zrc-sazu.si Chief editor for human geography/glavna urednica za humano geografijo: Mimi Urbanc; mimi@zrc-sazu.si Chief editor for regional geography/glavni urednik za regionalno geografijo: Drago Kladnik; drago.kladnik@zrc-sazu.si Chief editor for spatial planning/glavni urednik za regionaln o planiranje: Janez Nared; janez.nared@zrc-sazu.si Chief editor for urban geography/glavni urednik za urbano geografijo: David Bole; david.bole@zrc-sazu.si Chief editor for geographic information systems/glavni urednik za geografske informacijske sisteme: Rok Ciglič; rok.ciglic@zrc-sazu.si

Chief editor for environmental protection/glavni urednik za varstvo okolja: Aleš Smrekar; ales.smrekar@zrc.sazu Editorial assistant/uredniški pomočnik: Matjaž Geršič; matjaz.gersic@zrc.sazu

Published by/izdajatelj: Geografski inštitut Antona Melika ZRC SAZU

Issued by/založnik: Založba ZRC

Co-issued by/sozaložnik: Slovenska akademija znanosti in umetnosti

Address/Naslov: Geografski inštitut Antona Melika ZRC SAZU, Gosposka ulica 13, SI - 1000 Ljubljana, Slovenija

The papers are available on-line/prispevki so dostopni na medmrežju:

http://ags.zrc-sazu.si (ISSN: 1581-8314)

Ordering/naročanje:

Založba ZRC

Novi trg 2, p. p. 306, SI - 1001 Ljubljana, Slovenija

Phone/telefon: +386 (0)1 4706464

Fax/faks: +386 (0)1 4257794

E-mail/e-pošta: zalozba@zrc-sazu.si

Annual subscription/letna naročnina: $20 €$ for individuals/za posameznike, $28 €$ for institutions/za ustanove. Single issue/cena posamezne številke: $12,50 €$ for individuals/za posameznike, $16 €$ for institutions/za ustanove.

Cartography/kartografija: Geografski inštitut Antona Melika ZRC SAZU

Translations/prevodi: DEKS, d.o.o.

DTP/prelom: SYNCOMP, d.o.o.

Printed by/tiskarna: Collegium Graphicum d. o. o.

Print run/naklada: 400 copies/izvodov

The journal is subsidized by the Slovenian Research Agency/revija izhaja s podporo Javne agencije za raziskovalno dejavnost Republike Slovenije.

The journal is indexed also in/revija je vključena tudi v: SCIE - Science citation index expanded, Scopus, JCR - Journal Citation Report/Science Edition, ERIH PLUS, GEOBASE Journals, Current geographical publications, EBSCOhost, Geoscience e-Journals, Georef, FRANCIS, SJR (SCImago Journal \& Country Rank), OCLC WorldCat, and Google scholar, CrossRef.

Front cover photography: Agriculture plays an important role in both protecting and developing farmland and is an important factor facilitating development of other sectors (photograph: Matej Lipar).

Fotografija na naslovnici: Kmetijstvo ima pomembno vlogo pri varovanju in razvoju kmetijskih zemljišč in je pomemben dejavnik tudi pri razvoju drugih sektorjev (fotografija: Matej Lipar). 


\section{ASSESSING AVERAGE ANNUAL AIR TEMPERATURE TRENDS USING THE MANN-KENDALL TEST IN KOSOVO}

Milivoj B. Gavrilov, Slobodan B. Marković, Natalija Janc, Milena Nikolić, Aleksandar Valjarević, Blaž Komac, Matija Zorn, Milan Punišić†, Nikola Bačević

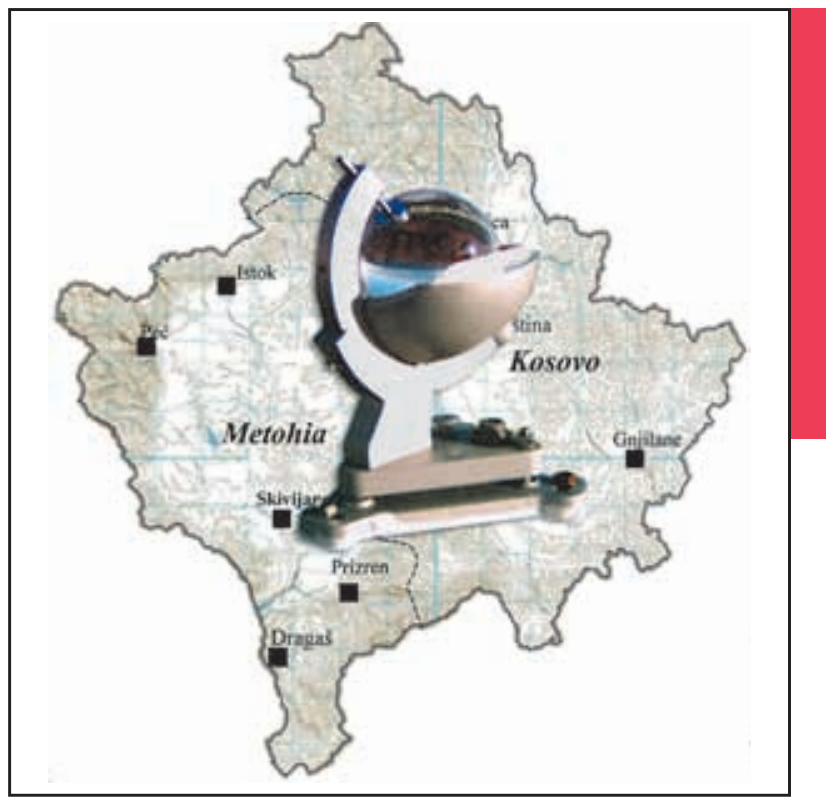

Temperatures were confirmed to rise in Kosovo in the last decades. 
DOI: https://doi.org/10.3986/AGS.1309

UDC: $911.2: 551.524(497.115)$

COBISS: 1.01

\title{
Assessing average annual air temperature trends using the Mann-Kendall test in Kosovo
}

\begin{abstract}
The annual trends of surface mean monthly air temperature and monthly extreme temperatures were analyzed from ten meteorological stations in Kosovo. The data refer to observation periods between 1949 and 1999 for four stations, and observation periods between 1965 and 1999 for the remaining six stations. Trends were analyzed for nine time series. Positive trends were found in six series, and negative trends were found in three series. After an assessment of these trends using the Mann-Kendall test, positive trends were confirmed in four series, a negative trend was confirmed in one series, and in one series there was no trend, whereas trends were characterized as slightly positive in two time series and slightly negative in one series.
\end{abstract}

KEY WORDS: air temperature trends, climate change, Mann-Kendall test, Kosovo

\section{Ocena trendov povprečnih letnih temperatur zraka na Kosovu $\mathrm{z}$ uporabo Mann-Kendallovega testa}

POVZETEK: V raziskavi so bili analizirani letni trendi povprečnih in ekstremnih mesečnih temperatur zraka, izmerjenih na desetih meteoroloških postajah na Kosovu. Podatki se pri štirih postajah nanašajo na opazovalno obdobje 1949-1999, pri preostalih šestih postajah pa na opazovalno obdobje 1965-1999. Trendi so bili analizirani za devet časovnih nizov. Pozitivni trendi so bili ugotovljeni v šestih nizih, negativni pa $v$ treh. Po oceni teh trendov $z$ uporabo Mann-Kendallovega testa so bili pozitivni trendi potrjeni $\mathrm{v}$ štirih nizih, negativni trend je bil potrjen $\mathrm{v}$ enem nizu, $\mathrm{v}$ enem nizu trenda ni bilo, rahlo pozitivni trendi so bili potrjeni $v$ dveh časovnih nizih in rahlo negativni $v$ enem nizu.

KLJUČNE BESEDE: trendi temperatur zraka, podnebne spremembe, Mann-Kendallov test, Kosovo

Milivoj B. Gavrilov, Slobodan B. Marković, Nikola Bačević

Department of Geography, Tourism and Hotel Management,

Faculty of Sciences, University of Novi Sad

gavrilov.milivoj@gmail.com, slobodan.markovic@dgt.uns.ac.rs,

nikolabacevic@yahoo.com

Natalija Janc

natalijanc@earthlink.net

\section{Milena Nikolić}

Belgrade Business School, Higher Education Institution for Applied Studies

milenan80@yahoo.com

\section{Aleksandar Valjarević}

Mathematical Institute of the Serbian Academy of Sciences and Arts

valjarkosmos@yahoo.com

\section{Blaž Komac, Matija Zorn}

Anton Melik Geographical Institute, Research Centre of the Slovenian

Academy of Sciences and Arts

blaz@zrc-sazu.si, matija.zorn@zrc-sazu.si 


\section{Milan Punišić}

Ministry of Natural Resources, Mining and Spatial Planning

The paper was submitted for publication on November $11^{\text {th }}, 2014$.

Uredništvo je prispevek prejelo 11. novembra 2014. 


\section{Introduction}

According to the Intergovernmental Panel on Climate Change (IPCC 2007) report, the average global surface air temperature of the world has increased by $0.7^{\circ} \mathrm{C}$ in the last hundred years. Klein Tank et al. (2002) showed that trends in average temperature increased in the period between 1946 and 1999 in Europe. This increase in global and regional temperature varies seasonally and regionally. In Europe the trends are higher in central and north-eastern areas and in mountainous regions, whereas lower trends are found in the Mediterranean region and temperatures are increasing higher in winter than summer (all during the period from 1977 to 2000; Alcamo et al. 2007).

Historically, the climate of Kosovo has generally been analyzed as part of the climate of Serbia and Yugoslavia. Using extreme temperatures at fifteen meteorological stations in Serbia, Unkašević and Tošić (2013) suggested that the climate in the region warmed up between 1949 and 2009. Analyzing data between 1949 and 2007, Unkašević and Tošić (2009a) found that a slow decrease in summer temperatures until 1975 was followed by a temperature increase lasting until 2007. In addition to these papers, other recent works addressing the climate in Serbia with and without Kosovo have been published (Jovanović et al. 2002; Gburčik et al. 2006; Đorđević 2008; Unkašević and Tošić 2009b; Gavrilov et al. 2010; 2013; Pavlović Berdon 2012; Hrnjak et al. 2014; Tošić et al. 2014; Gavrilov et al. 2015; 2016). In addition, the weather and climate of Kosovo were investigated in the work of Sokolović et al. (1984).

This study focuses on average annual air temperature trends in Kosovo from 1949 to 1999 and from 1965 to 1999 . The first period contains nearly two thirty-year-climate cycles, and the second contains more than one thirty-year-climate cycle. Therefore the results are proper indicators for recent climate change.

\section{Area and data}

\subsection{Study area}

Kosovo is located in the southwestern part of the Balkan Peninsula and covers an area of $10,887 \mathrm{~km}^{2}$ (Figure 1). Its geomorphological characteristics and geographical location divide it into two regions; Kosovo proper in the east is a plateau with a relatively consistent elevation, and Metohija in the west is a hilly area bordered by high mountains. The climate of Kosovo is moderate continental with cold winters and warm summers, with a great range of extreme temperatures and a non-uniform distribution of rainfall. The average annual air temperature is $10.8^{\circ} \mathrm{C}$, and the annual amount of precipitation between 1949 and 1999 was $669 \mathrm{~mm}$ (Internet 1).

\subsection{Data}

This work contains an analysis of surface air temperature trends obtained from ten meteorological stations. The locations of the stations are presented in Figure 1, and their main parameters are given in Table 1

Table 1: List of meteorological stations and their geographical coordinates and elevations.

\begin{tabular}{|c|c|c|c|c|}
\hline Number & Meteorological station & Elevation (m) & Latitude (N) & Longitude $\left({ }^{\circ} \mathrm{E}\right)$ \\
\hline \multicolumn{5}{|c|}{ Stations operated from 1949 to 1999} \\
\hline 1 & Kosovska Mitrovica & 510 & $42^{\circ} 53^{\prime}$ & $20^{\circ} 52^{\prime}$ \\
\hline 2 & Peć & 498 & $42^{\circ} 40^{\prime}$ & $20^{\circ} 18^{\prime}$ \\
\hline 3 & Prizren & 402 & $42^{\circ} 13^{\prime}$ & $20^{\circ} 44^{\prime}$ \\
\hline 4 & Priština & 573 & $42^{\circ} 39^{\prime}$ & $21^{\circ} 09^{\prime}$ \\
\hline \multicolumn{5}{|c|}{ Stations operated from 1965 to 1999} \\
\hline 5 & Istok & 465 & $42^{\circ} 47^{\prime}$ & $20^{\circ} 30^{\prime}$ \\
\hline 6 & Skivijane & 415 & $42^{\circ} 28^{\prime}$ & $20^{\circ} 21^{\prime}$ \\
\hline 7 & Suva Reka & 420 & $42^{\circ} 21^{\prime}$ & $20^{\circ} 49^{\prime}$ \\
\hline 8 & Gnjilane & 520 & $42^{\circ} 28^{\prime}$ & $21^{\circ} 29^{\prime}$ \\
\hline 9 & Uroševac & 580 & $42^{\circ} 23^{\prime}$ & $21^{\circ} 10^{\prime}$ \\
\hline 10 & Dragaš & 1060 & $42^{\circ} 04^{\prime}$ & $20^{\circ} 39^{\prime}$ \\
\hline
\end{tabular}


in accordance with the Republic Hydrometeorological Service of Serbia. Meteorological stations were divided into two groups, depending on the periods in which they were first established and operational. The first group consists of four stations that operated from 1949 to 1999, and the second group consists of the remaining six stations, which operated from 1965 to 1999. Nine of the stations have a relatively uniform elevation, varying between $402 \mathrm{~m}$ and $580 \mathrm{~m}$, whereas the Dragaš station has an elevation of 1,060 m (in this paper it is referred to as a mountain station).

In order to obtain trends, we used three data sets: monthly mean temperatures, monthly maximum temperatures, and monthly minimum temperatures for all stations. From the monthly temperatures, the average annual mean temperatures, average annual maximum temperatures, and average annual minimum temperatures were calculated. Finally, from these three types of average annual temperatures, new data sets were derived, marked as: $T, T_{x}$, and $T_{n}$, respectively, for trend calculations for Kosovo (K) over two periods: 1949-1999 (P1) from four stations (Kosovska Mitrovica, Peć, Prizren, and Priština) and 1965-1999 (P2)

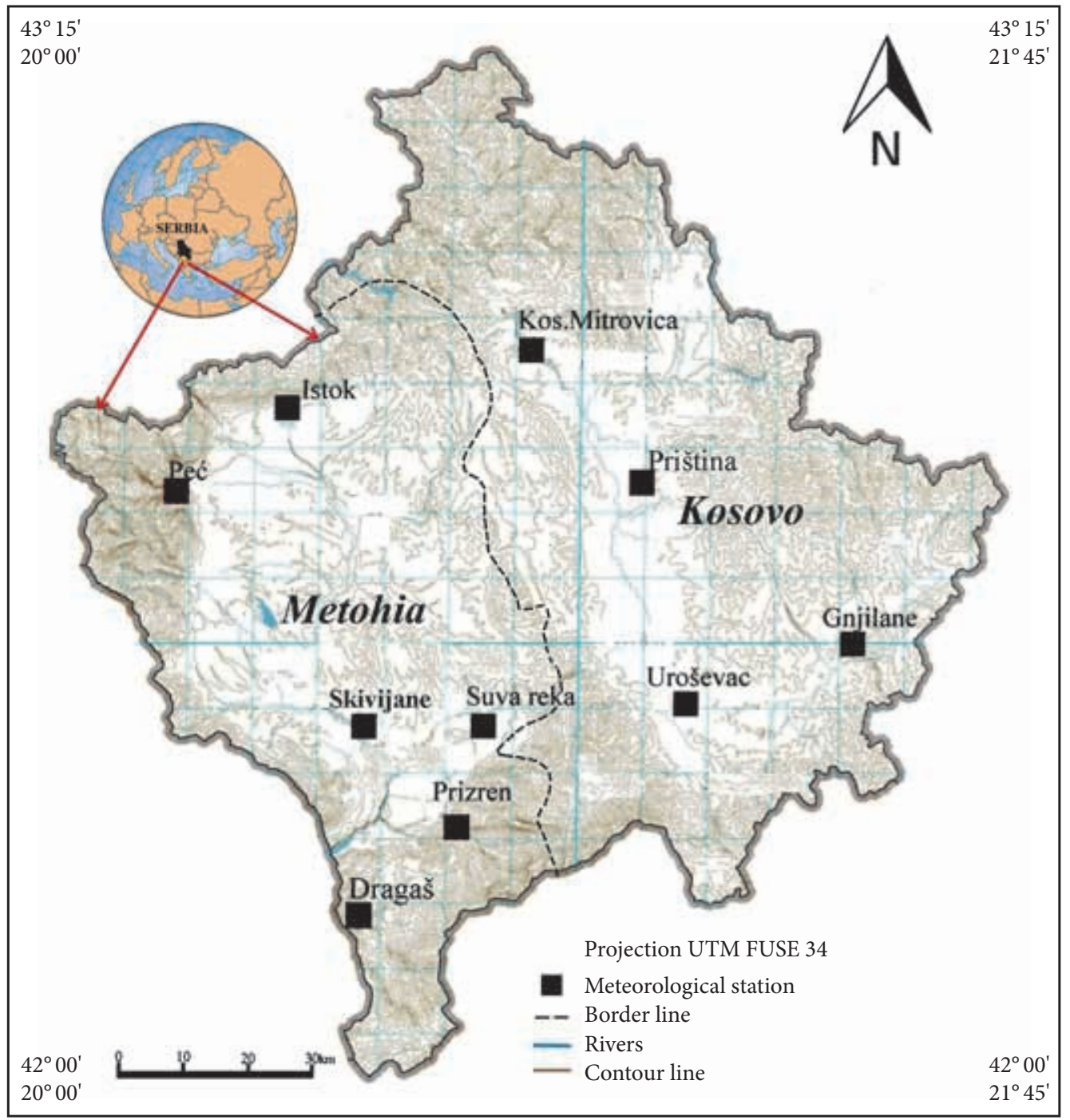

Figure 1: Kosovo. 
from five stations (Istok, Skivijane, Suva Reka, Gnjilane, and Uroševac); whereas Dragaš (D) was treated as a special data set because it is a mountain station, with data available for the period from 1965 to 1999 (P2). Each of these data sets is marked with an acronym consisting of the abbreviation for the territory/station, period, and type of temperature. In total, all nine data sets (time series) were used for trend calculation (Table 2).

Table 2: List of nine time series to calculate air temperatures trends.

\begin{tabular}{lcc}
\hline Territory/station & 1949-1999 (P1) & 1965-1999 (P2) \\
\hline \multirow{3}{*}{ Kosovo (K) } & K-P1-T & K-P2-T \\
& K-P1-T & K-P2- \\
& K-P1-T & K-P2-T \\
\hline \multirow{2}{*}{ Dragaš (D) } & - & D-P2-T \\
& - & D-P2-T \\
& - & D-P2-T \\
\hline
\end{tabular}

Before the previous calculation, the homogeneity of the temperature data was examined according to the Alexandersson (1986) test. The test showed that the time series are not non-homogeneous for a significance level of $5 \%$.

\section{Methods}

Temperature trends were analyzed for nine time series using two statistical approaches: calculation of the linear temperature trend equation and application of the Mann-Kendall test.

The first approach was to calculate the tendency (trend) equation of temperature using linear interpolation of the average annual temperatures (Wibig and Glowicki 2002). This method was used to determine the sign of the temperature trends and the trend magnitude (Gavrilov et al. 2015; 2016) as the difference in temperatures between the beginning and end of both periods P1 and P2.

The second statistical approach used the Mann-Kendall test (Kendall 1975; Gilbert 1987) to indicate statistically significant trends. The Mann-Kendall test is widely used in analysis of climatologic time series; for example, temperature and precipitation (Karmeshu 2012), extreme temperatures (Wibig and Glowicki 2002), hail (e.g., Gavrilov et al. 2010, 2013), aridity (Hrnjak et al. 2014), evapotranspiration (Tabari et al. 2011), and atmospheric deposition (Drapela and Drapelova 2011), and also in hydrological time series (Yue and Wang 2004) and other geophysical time series, such as soil freezing and thawing (Sinha and Cherkauer 2007) because it is simple and robust, and it can cope with missing values and values below the detection limit.

In using the Mann-Kendall test to define statistically significant trends, two hypotheses were tested: the null hypothesis, $H_{0}$, that there is no trend in the time series, and the alternative hypothesis, $H_{\mathrm{a}}$, that there is a trend in the time series for a given significance level. Probability $p$ in percent (Karmeshu 2012; Gavrilov et al. 2016) was calculated to determine the level of confidence in the hypothesis. If the computed value $p$ is lower than the chosen significance level $\alpha$ (e.g., $\alpha=5 \%$ ), the $H_{0}$ (there is no trend) should be rejected, and the $H_{\mathrm{a}}$ (there is a significant trend) should be accepted; and if $p$ is greater than the significance level $\alpha$ then the $H_{0}$ is accepted (or cannot be rejected). For calculating probability $p$ and hypothesis testing, XLSTAT statistical analysis software was employed (Internet 2).

It is considered that accepting the $H_{\mathrm{a}}$ indicates that a trend is statistically significant. On the other hand, acceptance of the $H_{0}$ implies that there is no trend (no change), whereas often in practice the trend equation indicates the opposite; that is, that there is a trend. Therefore, to reduce the contradictions in analyzing the temperature trends between two independent statistical approaches - the trend equation and the Mann-Kendall test - the modified interpretation of the Mann-Kendall test will be offered. Moreover, this interpretation makes it possible to obtain more diverse results.

It is quite clear that, with decreasing probability $p$, statistical confidence in the $H_{0}$ decreases and confidence in the $H_{\mathrm{a}}$ increases, and vice versa. Because probability $p$ takes values between $0 \%$ and $100 \%$, for the purposes of this study a modified interpretation of the Mann-Kendall test was introduced and four levels of confidence were defined (Gavrilov et al. 2015; 2016). When the computed probability $p$ is: (1) less or equal to $5 \%$, the trend is significantly positive/negative; (2) greater than $5 \%$ and less than or equal to $30 \%$, 
the trend is moderately positive/negative; (3) greater than $30 \%$ and less than or equal to $50 \%$, the trend is slightly positive/negative; and (4) greater than $50 \%$, there is no trend. As can be seen, in cases (1) and (4) both interpretations of the Mann-Kendall test have the same meaning; namely, that there is a significant trend and that there is no trend. Differences occur in cases (2) and (3), where the Mann-Kendall test claims there is no trend, and the modified Mann-Kendall test allows a trend with reduced levels of confidence.

\section{Results and discussion}

\subsection{The values of trends}

By applying both statistical approaches to each of the nine time series in Table 2, nine cases are obtained (Table 3).

Table 3: The trend equation $y$, the trend magnitude $\Delta y$, and probability $p$ of the confidences for all time series.

\begin{tabular}{llcc}
\hline Time series & Trend equation & $\Delta y\left(^{\circ} \mathrm{C}\right)$ & $p(\%)$ \\
\hline K-P1-T & $y=-0.006 x+10.97$ & 0.3 & 25 \\
K-P1-T & $y=0.013 x+23.50$ & -0.7 & 17 \\
K-P1-T & $y=0.012 x-1.40$ & -0.6 & 4.5 \\
K-P2-T & $y=0.021 x+10.31$ & -0.7 & 1 \\
K-P2-T & $y=0.024 x+23.42$ & -0.8 & 2 \\
K-P2-T & $y=0.011 x-2.17$ & -0.4 & 24 \\
D-P2-T & $y=-0.003 x+8.31$ & 0.1 & 1 \\
D-P2-T & $y=0.070 x+20.41$ & -2.5 & 1 \\
D-P2-T & $y=-0.047 x-1.76$ & 1.7 & \\
\hline
\end{tabular}

In Table 3 the first column is the time series; the second column is the linear trend equation, where $y$ is the average annual value of the temperature in ${ }^{\circ} \mathrm{C}$ and $x$ is the time in years; $\Delta y$ is the trend magnitude in ${ }^{\circ} \mathrm{C}$; and $p$ is the probability in percent, $\alpha=5 \%$ is the significance level (it is the same in all cases).

\subsection{Evaluation of trends}

In strictly formal terms, as evidenced by the trend equations in Table 3, in all cases some trends can be observed. However, not all trends have the same sign, magnitude, and probability. To obtain the final evaluation of temperature trends, values from Table 3, Figures 2-4, and the results of hypothesis testing were used.

Figure 2 and the trend equations for the time series K-P1-T, K-P1- $\mathrm{T}_{\mathrm{x}}$, and $\mathrm{K}-\mathrm{P} 1-\mathrm{T}_{\mathrm{n}}$ show that the trends are negative once and positive twice, respectively. Mann-Kendall test will prove whether these statements are true. Because the probabilities $p$ are greater than the significance level, $\alpha=5 \%$, the $H_{0}$ cannot be rejected in the first two cases. The risk of rejecting the $H_{0}$ while it is true are $25 \%$ and $17 \%$, respectively. Because the $p$ in K-P1- $\mathrm{T}_{\mathrm{n}}$ is lower than the significance level, the $H_{0}$ should be rejected and the $H_{\mathrm{a}}$ should be accepted. The statement that there is a trend is correct with a probability greater than $95 \%$. In accordance with the modified Mann-Kendall test, these three trends are characterized as moderately negative, moderately positive, and significantly positive, respectively.

Figure 3 and the trend equations for the time series K-P2-T, K-P2- $\mathrm{T}_{\mathrm{x}}$, and K-P2- $\mathrm{T}_{\mathrm{n}}$ show that the trends are positive in all cases. Mann-Kendall test will prove whether these statements are true. Because the probabilities $p$ in K-P2-T and K-P2- $\mathrm{T}_{\mathrm{x}}$ are lower than the significance level, $\alpha=5 \%$, the $H_{0}$ should be rejected and the $H_{\mathrm{a}}$ should be accepted in both cases. The statement that there are trends is correct with a probability greater than $98 \%$. Because the $p$ in K-P2- $\mathrm{T}_{n}$ is greater than the significance level, the $H_{0}$ cannot be rejected. The risk of rejecting the $H_{0}$ while it is true is $24 \%$. In accordance with the modified Mann-Kendall test, these cases are characterized as significantly positive twice and moderately positive once, respectively.

Figure 4 and the trend equations for the time series D-P2-T, D-P2- ${ }_{x}$, and D-P2- $T_{n}$ show that the trends are negative, positive, and negative, respectively. Mann-Kendall test will prove whether these statements are true. Because probability $p$ in D-P2-T is greater than the significance level, $\alpha=5 \%$, the $H_{0}$ cannot be rejected. 


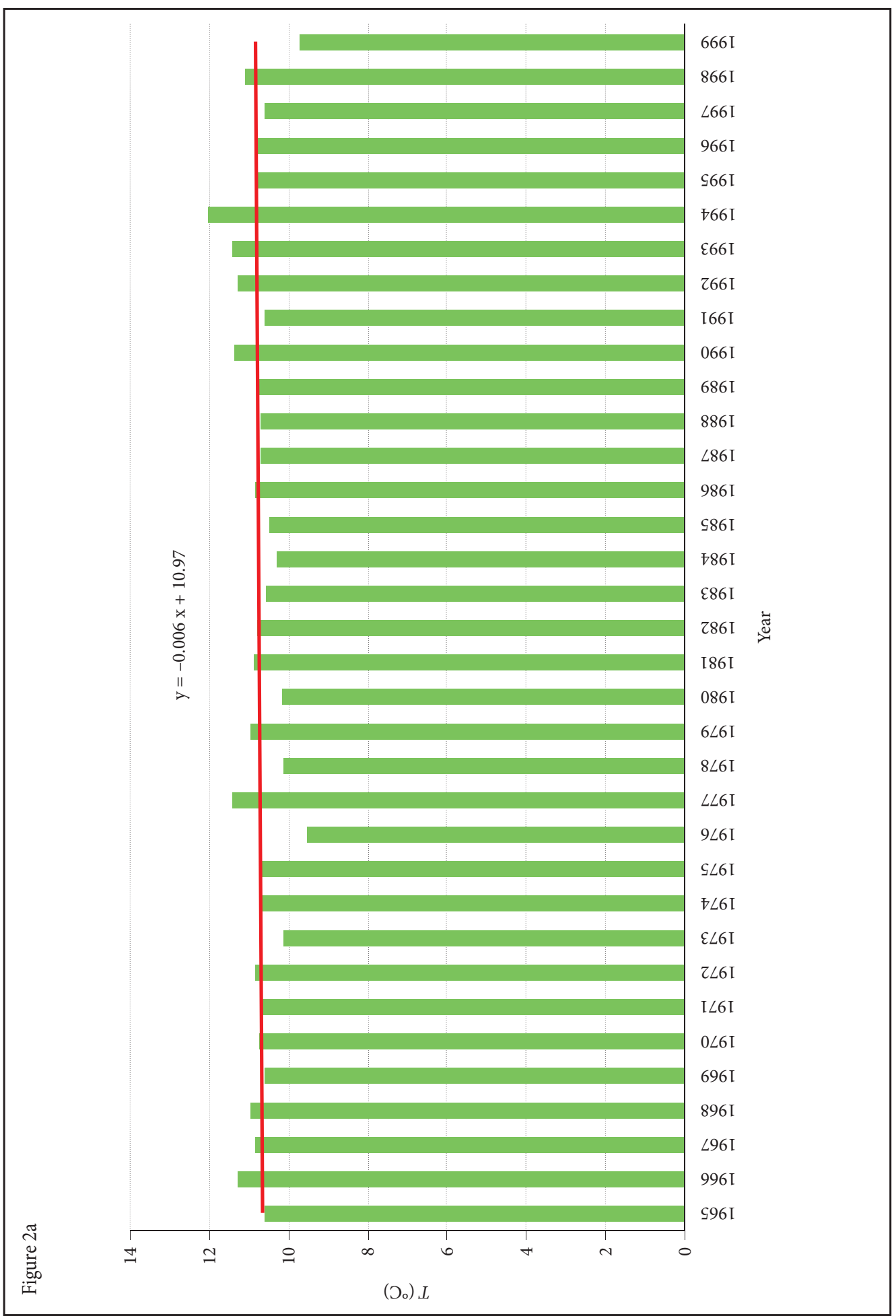


Acta geographica Slovenica, 58-1, 2018

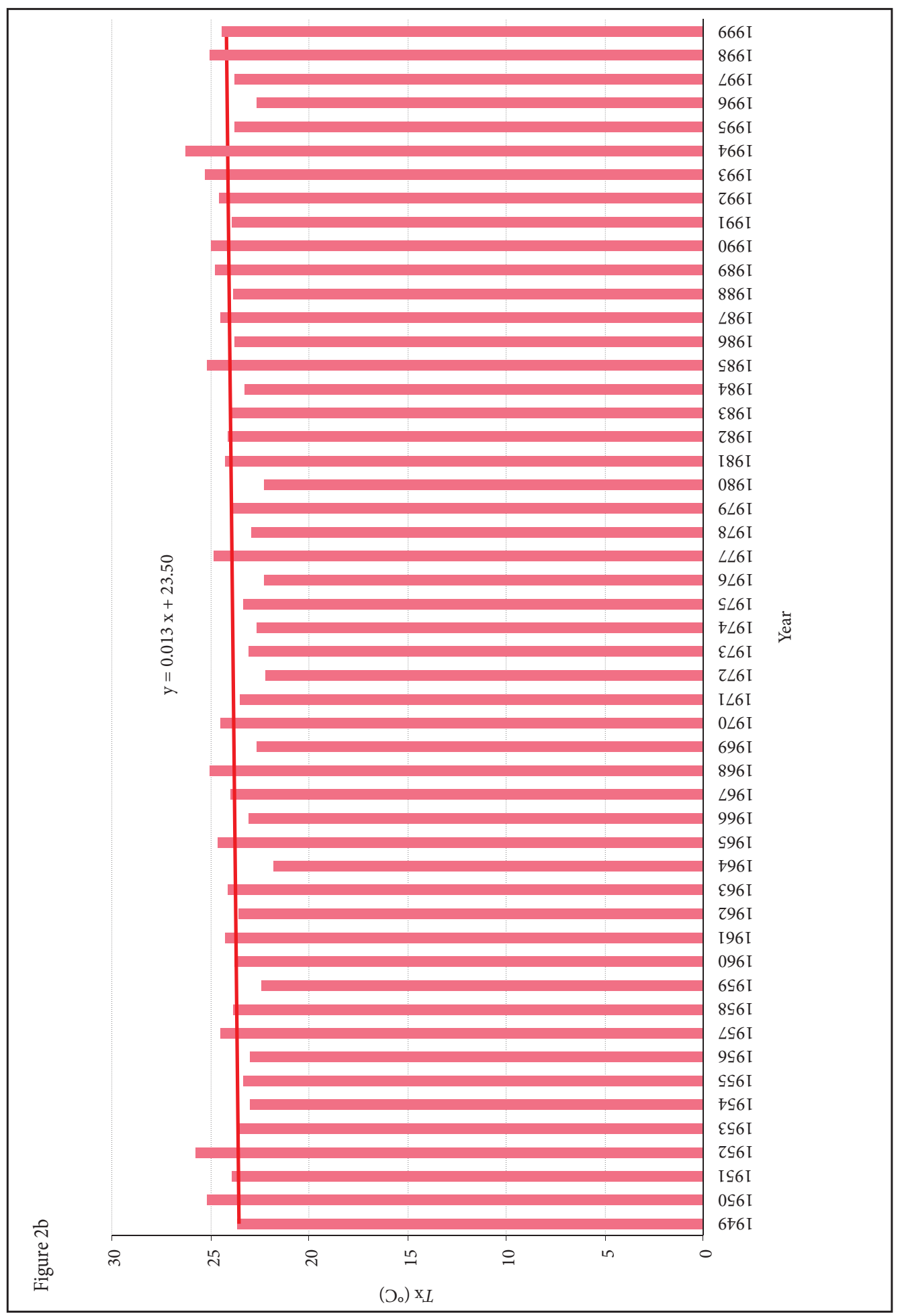




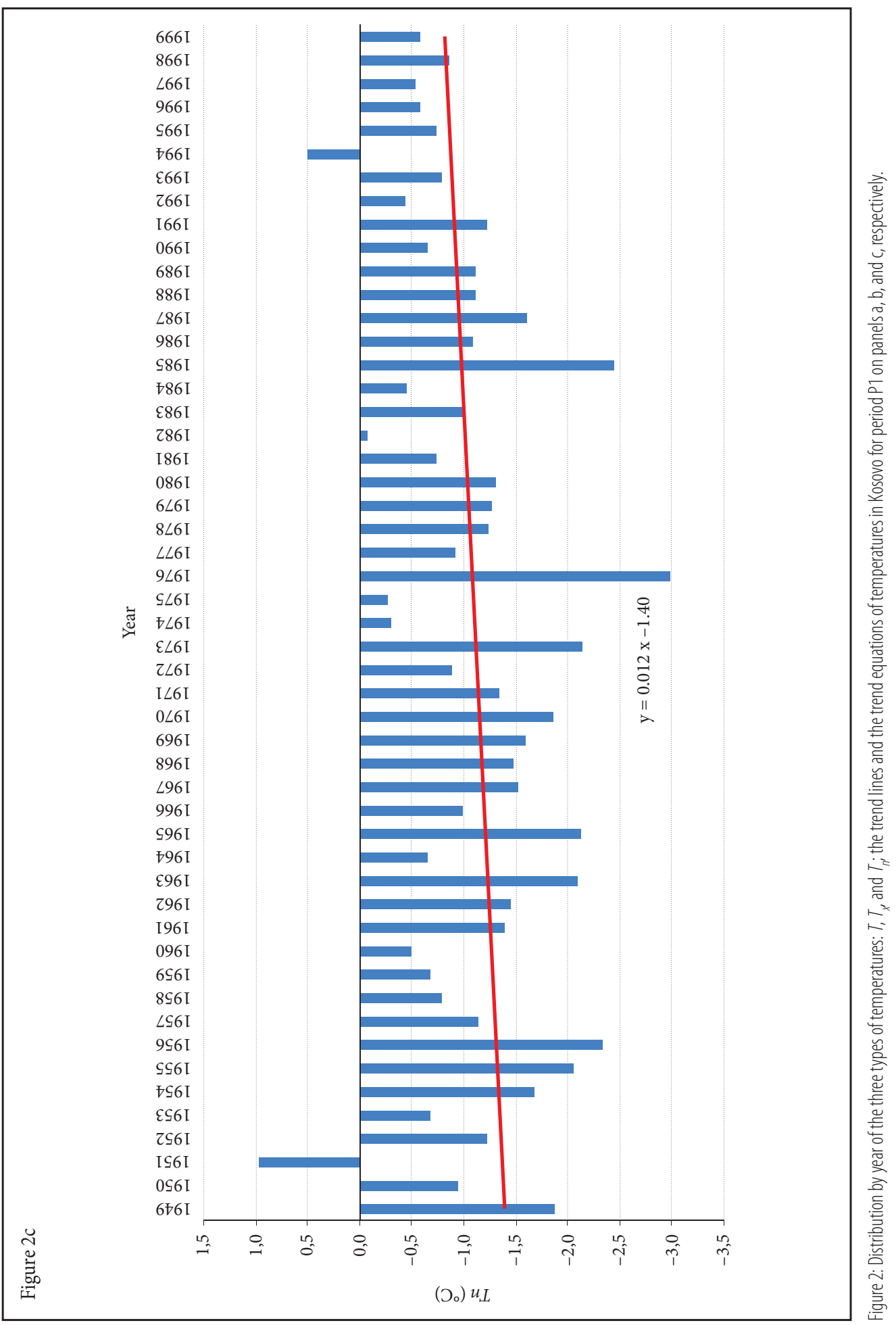




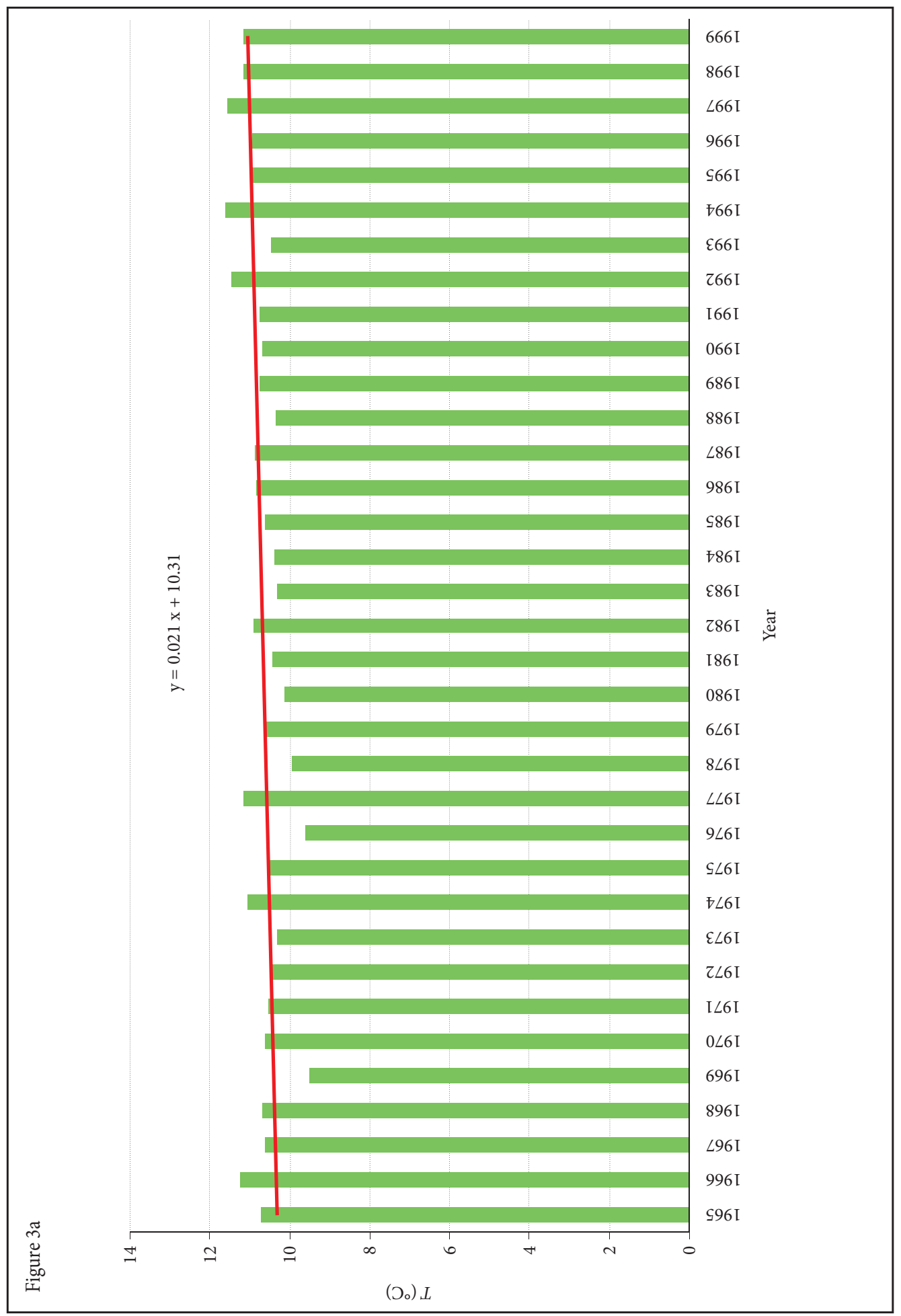




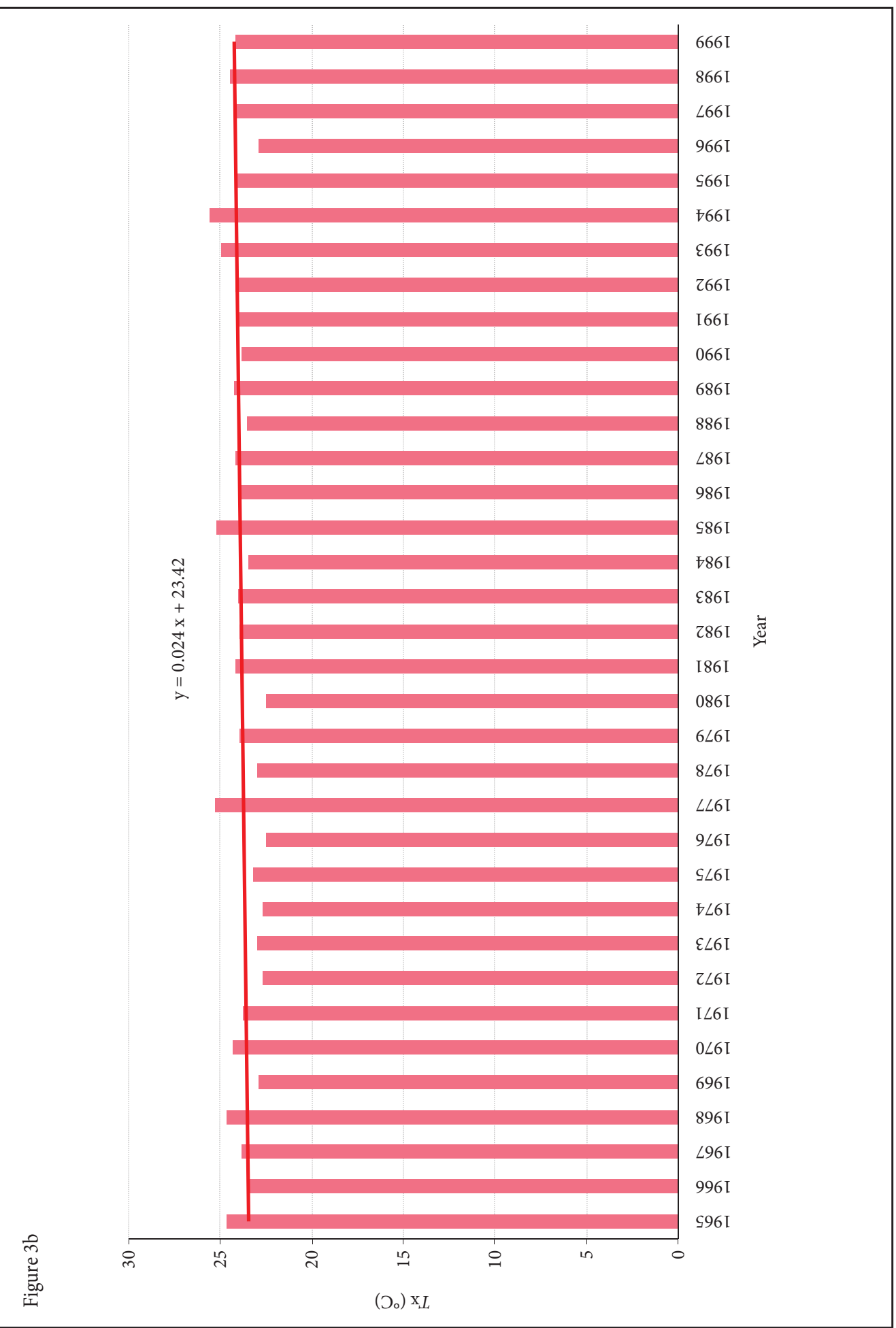




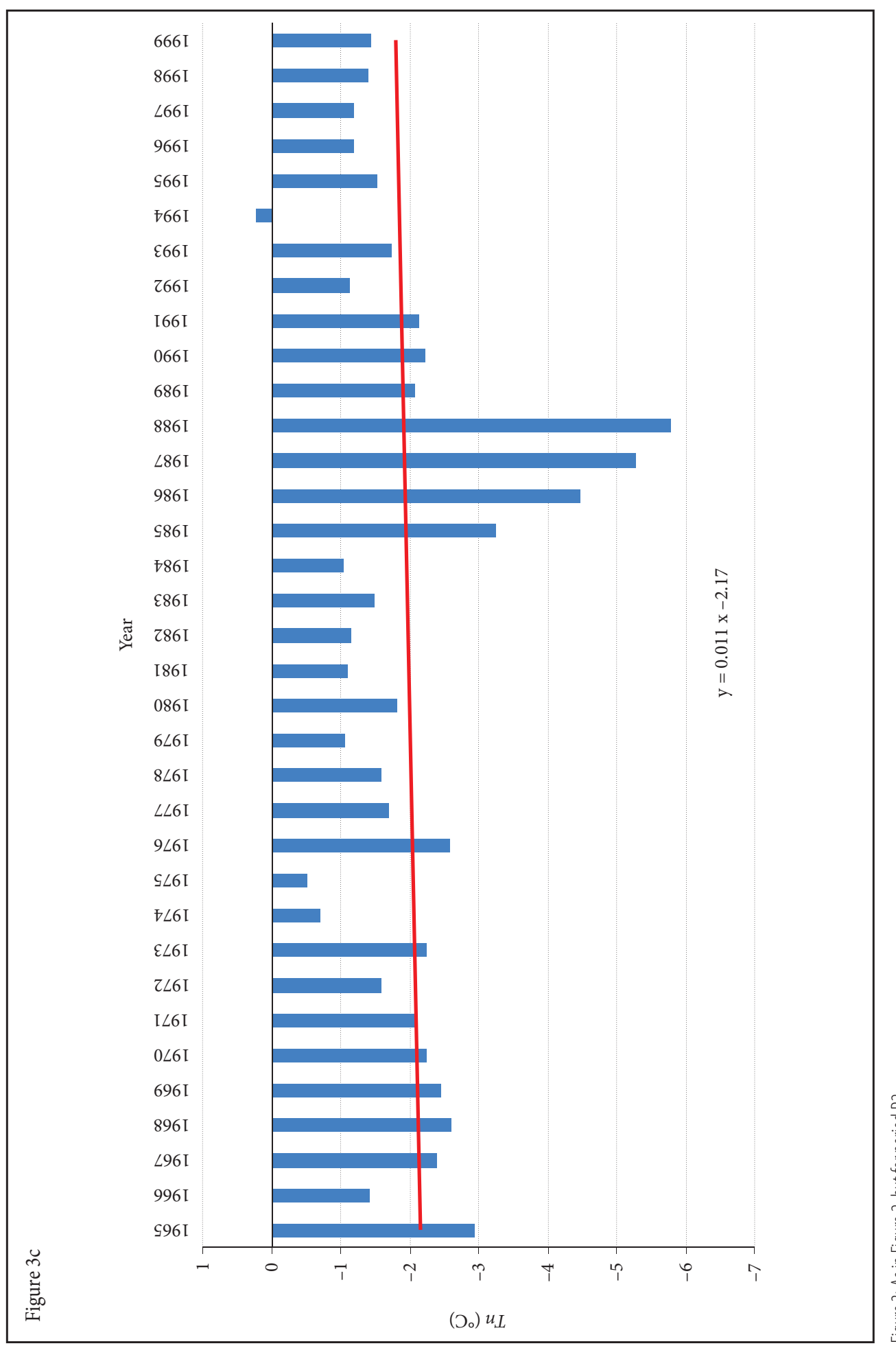




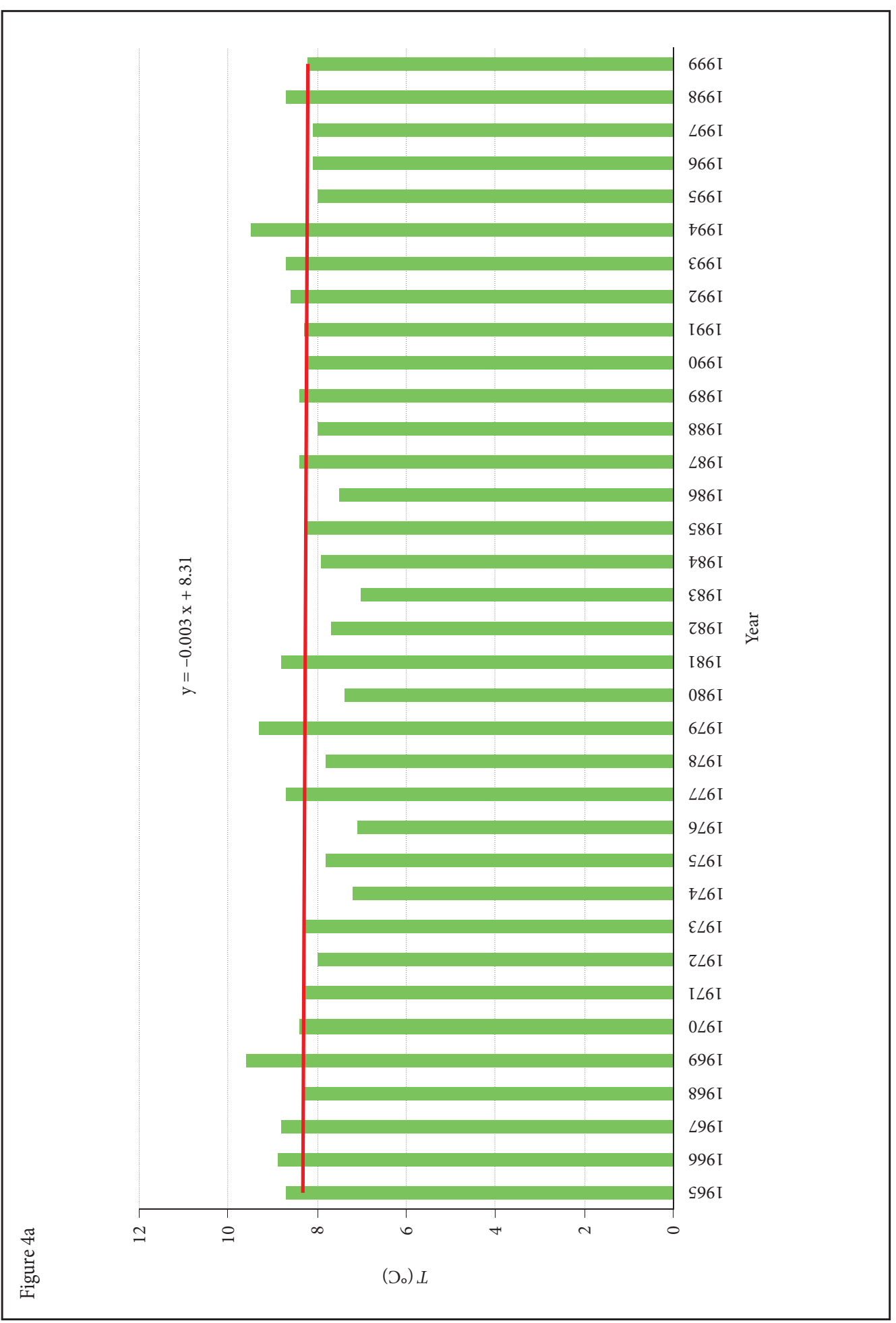




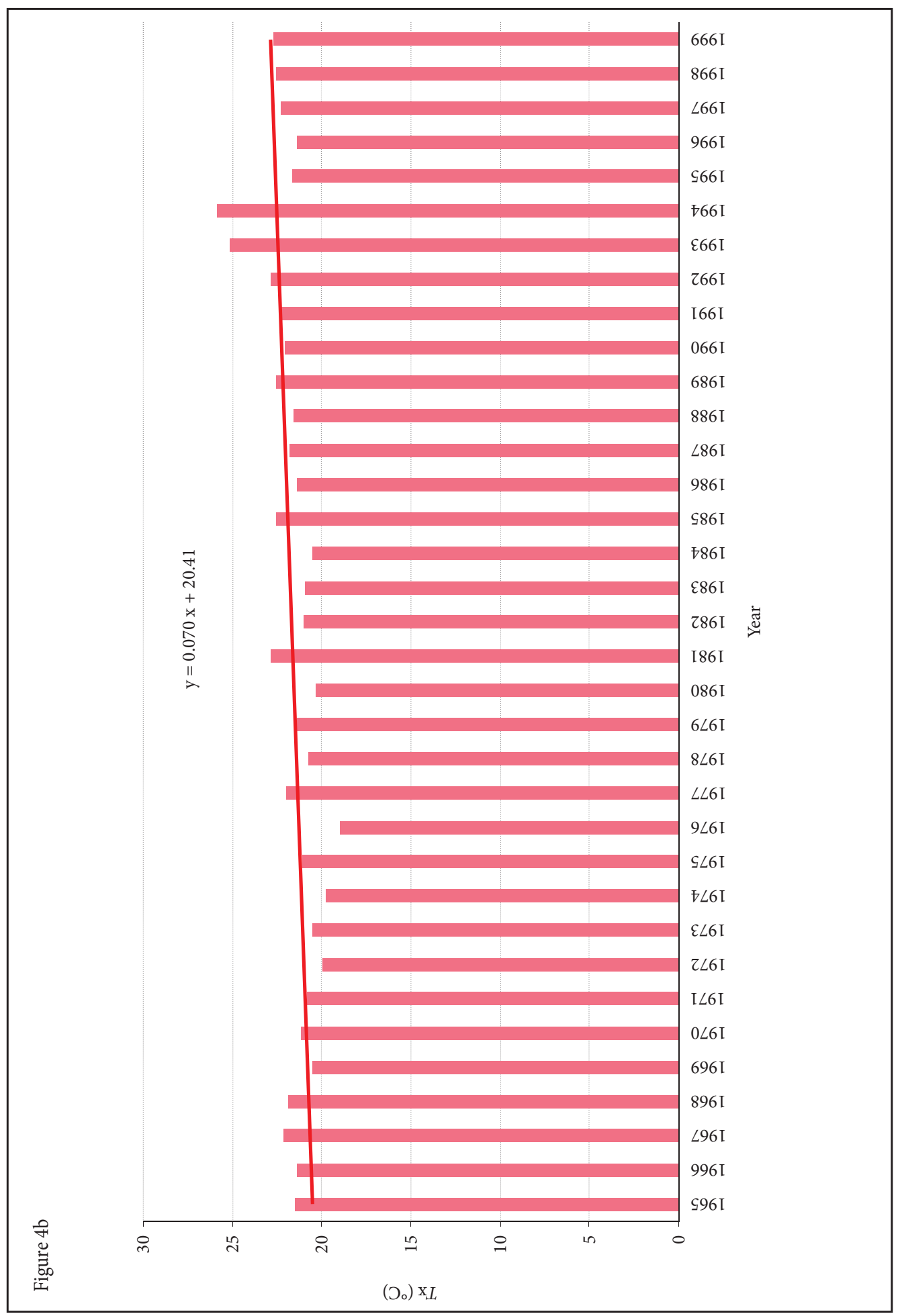




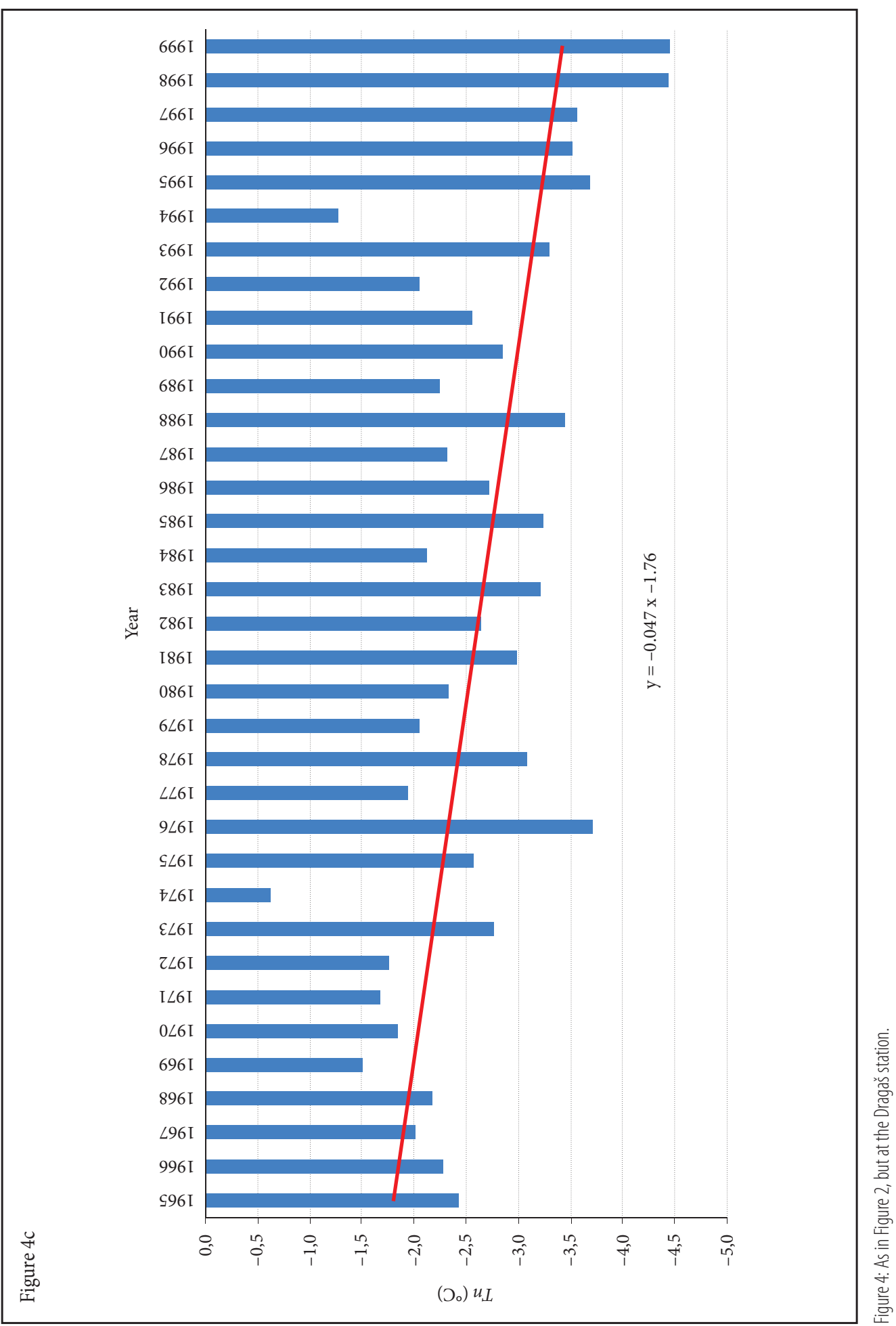


The risk of rejecting the $H_{0}$ while it is true is $89 \%$. Because the probabilities $p$ in D-P2-T and D-P2-T are lower than the significance level, the $H_{0}$ should be rejected and the $H_{\mathrm{a}}$ should be accepted in both cases. The statement that there are trends is correct with a probability greater than $99 \%$. Now, the trends are characterized as no trend, significantly positive, and significantly negative, respectively. It should be noted that in the case D-P2-T the $\Delta y$ is equal to the standard error of the temperature measurement, and so it is also considered no trend.

\section{Conclusions}

The main results of the analysis of temperature trends in Kosovo are shown in Table 4.

Table 4: The main results of the analysis of trends.

\begin{tabular}{|c|c|c|}
\hline Time series & Trend equation & Modified Mann-Kendall test \\
\hline K-P1-T & Negative trend & Negative moderate trend \\
\hline K-P1-T, & Positive trend & Positive moderate trend \\
\hline$K-P 1-T_{n}^{x}$ & Positive trend & Positive significant trend \\
\hline$K-P 2-T^{n}$ & Positive trend & Positive significant trend \\
\hline K-P2-T & Positive trend & Positive significant trend \\
\hline$K-P 2-T_{n}^{x}$ & Positive trend & Positive moderate trend \\
\hline D-P2-T & Negative trend & No trend \\
\hline D-P2-T & Positive trend & Positive significant trend \\
\hline$D P-2-T_{n}^{x}$ & Negative trend & Negative significant trend \\
\hline
\end{tabular}

Based on the trend equations, positive trends were found in six and negative trends were found in three time series. After applying the Mann-Kendall test, significantly positive trends were confirmed in four time series, a moderately positive trend was found in two time series, and a significantly negative trend, moderately negative trend, and no trend were found in a single case each.

From the results presented above, it is very difficult to derive an overall general rule, but some conclusions can be drawn. First, positive temperature trends dominate. All of them could be explained by the effects of global warming on Kosovo. This impact is most evident in the case of representative time series K-P2-T, which covers the 1980s and 1990s, when the effect of global warming was first detected in the region (Gavrilov et al. 2016). On the other hand, the representative case K-P1-T was also influenced by global warming, but no positive trend was noted. This can be explained by impacts from the 1960s and 1970s, when there were no signs of global warming (Hardy 2006).

In the case of the Dragaš mountain station, the results were very diverse. There, all three trends were found: positive, negative, and no trend. This case, as well as a detailed explanation of other cases, requires additional research.

In spite of the limited meteorological data available, the results presented provide insight into the climate dynamics of the region.

ACKNOWLEDGEMENTS: This study was supported by the Serbian Ministry of Science, Education and Technological Development, under grant nos. 176020 and III 44006. The authors are grateful for the support of Ivana Tošić, Ph.D. The authors sincerely appreciate the efforts of Valentina Janc in improving this manuscript.

\section{References}

Alexandersson, H. 1986: A homogeneity test applied to precipitation data. Journal of climatology 6-6. DOI: http://dx.doi.org/10.1002/joc.3370060607

Alcamo, J., Moreno, J. M. Nováky, B., Bindi, M., Corobov, R., Devoy, R. J. N., Giannakopoulos, C., Martin, E., Olesen, J. E., Shvidenko, A. 2007: Europe Climate Change 2007: Impacts, Adaptation and Vulnerability. Contribution of Working Group II to the Fourth assessment report of the Intergovernmental panel on climate change. Cambridge. 
Brázdil, R., Budíková, M., Auer, I., Böhm, R., Cegnar, T., Faško, P., Lapin, M., Gajić-Čapka, M., Zaninović, K., Koleva, E., Niedźwiedź, T., Ustrnul, Z., Szalai, S., Weber, R. O. 1996: Trends of maximum and minimum daily temperatures in central and southeastern Europe. International journal of climatology 16-7. DOI: http://dx.doi.org/10.1002/(SICI)1097-0088(199607)

Drapela, K., Drapelova, I. 2011: Application of Mann-Kendall test and the Sen's slope estimates for trend detection in deposition data from Bílý Kř́íž (Beskydy Mts., the Czech Republic) 1997-2010. Beskydy 4-2.

Đorđević, S. V. 2008: Temperature and precipitation trends in Belgrade and indicators of changing extremes for Serbia. Geographica Pannonica 12-2.

Gavrilov, M. B., Lazić, L., Pešić, A., Milutinović, M., Marković, D., Stanković, A., Gavrilov, M. M. 2010: Influence of hail suppression on the hail trend in Serbia. Physical geography 31-5. DOI: http://dx.doi.org/ 10.2747/0272-3646.31.5.441

Gavrilov, M. B., Lazić, L., Milutinović, M., Gavrilov, M. M. 2011: Influence of hail suppression on the hail trend in Vojvodina, Serbia. Geographica Pannonica 15-2.

Gavrilov, M. B., Marković, S. B., Zorn, M., Komac, B., Lukić, T., Milošević, M., Janićević, S. 2013: Is hail suppression useful in Serbia? - General review and new results. Acta geographica Slovenica 53-1. DOI: http://dx.doi.org/10.3986/AGS53302

Gavrilov, M. B., Marković, S. B., Jarad, A., Korać, V. M. 2015: The analysis of temperature trends in Vojvodina (Serbia) from 1949 to 2006. Thermal science. DOI: http://dx.doi.org/10.2298/TSCI150207062G

Gavrilov, M. B., Tošić, I., Marković, S. B., Unkašević, M., Petrović, P. 2016: The analysis of annual and seasonal temperature trends using the Mann-Kendall test in Vojvodina, Serbia. IDÖJÁRÁS (accepted). Budapest.

Gburčik, P., Gburčik, V., Gavrilov, M. B., Srdanović, V., Mastilović, S. 2006: Complementary regimes of solar and wind energy in Serbia. Geographica Pannonica 10-2.

Gilbert, R. O. 1987: Statistical methods for environmental pollution monitoring. New York. DOI: http://dx.doi.org/10.1016/j.gloplacha.2012.10.014

Hardy, J., T. 2006: Climate change - causes, effects and solutions. Chichester.

Hrnjak, I., Lukić, T., Gavrilov, M. B., Marković, S. B., Unkašević, M., Tošić, I. 2014: Aridity in Vojvodina, Serbia. Theoretical and applied climatology 115, 1-2. DOI: http://dx.doi.org/10.1007/s00704-013-0893-1

Internet 1: http://www.hidmet.gov.rs/ciril/meteorologija/klimatologija_godisnjaci.php (11.3.2014).

Internet 2: http://www.xlstat.com/en/ (25.5.2014).

IPCC 2007: Intergovenmental panel climate change. The physical science basis. Cambridge.

Jovanović, G., Reljin, I., Savić, T. 2002: NAO Influence on climate variability in FRY. 18th International conference on Carpathian meteorology. Belgrade.

Karmeshu, N. 2012: Trend detection in annual temperature \& precipitation using the Mann Kendall Test a case study to assess climate change on select states in the northeastern United States. Master's thesis, University of Pennsylvania. Philadelphia.

Kendall, M. G. 1975: Rank correlation methods. London.

Klein Tank, A. M. G., Wijngaard, J.B., Konnen, G. P., Bohm, R., Demaree, G., Gocheva, A., Mileta, M., Pashiardis, S., Hejkrlik, L., Kern-Hansen, C., Heino, R., Bessemoulin, P., Muller-Westermeier., G, Tzanakou, M., Szalai, S., Palsdottir, T., Fitzgerald, D., Rubin, S., Capaldo, M., Maugeri, M., Leitass, A., Bukantis, A., Aberfeld, R., VanEngelen, A.F. V., Forland, E., Mietus, M., Coelho, F., Mares, C., Razuvaev, V., Nieplova, E., Cegnar, T., López, J. A., Dahlstrom, B., Moberg, A., Kirchhofer, W., Ceylan, A., Pachaliuk, O., Alexander, L. V., Petrovic, P. 2002: Daily dataset of 20th-century surface air temperature and precipitation series for the European climate assessment. International journal of climatology 22-12. DOI: http://dx.doi.org/10.1002/joc.773

Pavlović Berdon, N. 2012: The impact of Arctic and North Atlantic oscillation on temperature and precipitation anomalies in Serbia. Geographica Pannonica 16-2.

Sinha, T., Cherkauer, K. A. 2008: Time series analysis of soil freeze and thaw processes in Indiana. Journal of hydrometeorology 9-5. DOI: http://dx.doi.org/10.1175/2008JHM934.1

Sokolović, G., Radičević, D., Ranković, S. 1984: Atlas klime Socijalističke Federativne Republike Jugoslavije. Beograd.

Tabari, H., Marofi, S., Aeini, A., Talaee, P. H., Mohammadi, K. 2011: Trend analysis of reference evapotranspiration in the western half of Iran. Agricultural and forest meteorology 151-2. DOI: http://dx.doi.org/ 10.1016/j.agrformet.2010.09.009 
Tošić, I., Hrnjak, I., Gavrilov, M. B., Unkašević, M., Marković, S. B., Lukić, T. 2014: Annual and seasonal variability of precipitation in Vojvodina, Serbia. Theoretical and applied climatology 117, 1-2. DOI: http://dx.doi.org/10.1007/s00704-013-1007-9

Unkašević, M., Tošić, I. 2009a: Changes in extreme daily winter and summer temperatures in Belgrade. Theoretical and applied climatology 95, 1-2. DOI: http://dx.doi.org/10.1007/s00704-007-0364-7

Unkašević, M., Tošić, I. 2009b: An analysis of heat waves in Serbia. Global and planetary change 65, 1-2. DOI: http://dx.doi.org/10.1016/j.gloplacha.2008.10.009

Unkašević, M., Tošić, I. 2013: Trends in temperature indices over Serbia: relationships to large-scale circulation patterns. International journal of climatology 33-15. DOI: http://dx.doi.org/10.1002/joc.3652

Wibig. J., Glowicki, B. 2002: Trends of minimum and maximum temperature in Poland. Climate research 20-2. DOI: http://dx.doi.org/10.3354/cr020123

Yue, S., Wang, C. 2004: The Mann-Kendall test modified by effective sample size to detect trend in serially correlated hydrological series. Water resources management 18-3. DOI: http://dx.doi.org/10.1023/ B:WARM.0000043140.61082.60 